See discussions, stats, and author profiles for this publication at:

http://www.researchgate.net/publication/273331873

\title{
Evaluation of availability of financial resources and manpower development in selected monotechnics in Nigeria
}

ARTICLE · OCTOBER 2014

DOI: $10.5367 /$ ihe. 2014.0219

DOWNLOADS

8

1 AUTHOR:

Onoriode Collins Potokri

University of South Africa

7 PUBLICATIONS 2 CITATIONS

SEE PROFILE
VIEWS

23 


\title{
Evaluation of availability of financial resources and manpower development in selected monotechnics in Nigeria
}

\section{Onoriode Collins Potokri}

\begin{abstract}
This research investigates manpower development and availability of financial resources in Nigerian monotechnic education. Monotechnics are single-subject institutions of higher learning that offer specialized programmes. A quantitative research design located within the positivist paradigm was adopted. A sample of 200 students and 80 members of staff was randomly selected from two public and two private monotechnics. A structured questionnaire was used and Chi-square and Pearson product moment correlation statistics were used to analyse the resulting data. The findings indicate that manpower development, in terms of the skills and competency of prospective graduates, is affected by the funding made available to these institutions. It was further found that the financial resources provided or otherwise available in monotechnics (whether privately or publicly owned) are inadequate. Recommendations are made based on the findings.
\end{abstract}

Keywords: financial resources; manpower development; monotechnics; Nigeria; quantitative research

Onoriode Collins Potokri is with the Department of Educational Leadership and Management, College of Education, University of South Africa (UNISA), Vudec Building, Corner of Van Der Walt and Skinner Streets, Pretoria 0002, South Africa. E-mail: potokc@unisa.ac.za; cnuvie@gmail.com.

The dynamism of education is perhaps applicable to every aspect of life. This explains why some scholars say that education is life, while others say that education is power. These views are responsible, arguably, for an increase in the quest for higher education in the $21 \mathrm{st}$ century. In response to the increasing demand, higher education institutions (HEIs) such as universities, polytechnics, colleges of education, monotechnics and other institutions are being established to meet contemporary challenges (Potokri, 2005). Farzaneh and
Moghadam (2003) argue that education is a key part of strategies to improve both the well-being of individuals and the economic and social development of societies. It is therefore important to consider that education implies a worthwhile activity and a process which results in both personal and societal development - both intrinsic and instrumental - giving the individual happiness and making the society progressive (Potokri, 2011).

In the Nigerian context, monotechnics are single-subject technological institutions offering 
specialized programmes in disciplines such as surveying, agriculture, fisheries, forestry, accountancy, nursing, mining, petroleum and languages (FRN, 2004). The structure and status of their programmes are equivalent to those in place at polytechnics and they are regulated by the National Board for Technical Education.The objectives of monotechnics, as highlighted in Nigeria's National Policy on Education, include providing the technical knowledge and skills necessary for the industrial, commercial and economic development of Nigeria, providing full-time or part-time training and instructional courses for the subjects for which the institution was established, training people able to apply scientific knowledge to solve, for example, environmental problems, and conducting applied research relevant to the growth of the nation (FRN, 2004; JAMB, 2011). Given these objectives, monotechnics should play an indispensable role in the growth and development of the nation.

The first institution of higher learning to be established in Nigeria was the Yaba Higher College (YHC), founded in 1934. Today, the institution is known as the Yaba College of Technology (YCT). Prior to 1934 (Potokri, 2005; 2011), a number of training schools and institutions categorized as monotechnics had already been established - for example, the survey school established in Lagos in 1908 and now operating in Oyo. Monotechnics maintain a two-tier programme of studies: the National Diploma (ND) and the Higher National Diploma (HND). As is the case with polytechnics, a one-year period of industrial experience is a prerequisite for entry into the HND courses. Monotechnic graduates - provided they meet the basic requirements for the course concerned - are allowed to join a degree programme in a university.

In the past, there were only a few monotechnics and these were predominantly government-run. More recently, however, their number has increased and many are owned, financed and managed by private individuals. Until recently, admission was through entrance examinations conducted by the individual institutions. Currently, however, the bulk of admissions is managed by the Joint Admission and Matriculation Board (JAMB) to ensure that admission is broad-based (JAMB, 2011). However, some institutions, such as the Baptist School of Nursing in Eku, Delta State, still conduct their own entrance examinations.

Most students, parents and the community at large find it difficult to distinguish between a monotechnic and any other higher education institution. This lack of recognition is probably due to the information and advice given to students at secondary schools and to the fact that less attention is given to monotechnic institutions by government.
Monotechnics, like other higher education institutions, face a number of problems relating to finance, politics, inadequate personnel, etc (Saint et al, 2003; Teferra and Altbach, 2004; Ogbogu, 2011). Financial resources in particular are the main driving force for the implementation of plans in any educational institution (Campbell, 2003) and, in general, are the bedrock of the existence of such institutions. For these reasons, this research - as a means of understanding the connectivity between finance and development, as well as the relationship between them - attempts to evaluate financial resources and manpower development in monotechnic education.

\section{Background}

Resources can be regarded in this context as a means to an end. The nature, size, quality and quantity of resources determine to an extent the existence, status, progress, development and sustenance of any country, organization or institution (Aina, 2005). Resourcing is a major challenge in many walks of life. It is one reason why people complain of poor governance, poor administration and poor management. From the perspective of economics, wants are unlimited but resources are limited. Therefore, all organizations either government or privately-owned - are faced with challenges related to finance. Resources can also be artificial or natural. Potokri $(2005 ; 2013)$ notes that resources could be in the form of money, people, equipment or materials, amongst others.

For the purpose of this research, 'financial resources' refers to money and related aspects of educational funding and finance. According to Okunamiri (2002), financial resources include government allocations, fees, levies, fund raising activities, community support, educational taxes and aid received from non-governmental organizations. Prior to the end of the Nigerian civil war in 1970, and up to 1974, the concept of resourcing in educational administration was seen merely from the perspective of what the heads of institutions or colleges would do in their institutions on a daily basis (Okunamiri, 2002). There was therefore no clear identification of resources and resources were not regularly allocated or sourced. This led to a lack of proper co-ordination and resulted in the absence of a meaningful relationship between resource availability, resource utilization and the implementation of educational plans directed at the attainment of the broad goals and national objectives of the educational system (Okunamiri, 2002; Foo Seong, 2008). This state of affairs caused gaps in the educational system in particular (Nwankwo, 1988).

Nwankwo (1988) notes that several factors were responsible for the gaps observed - and that the effect of 
these factors could have been minimized if the attention of the government and other stakeholders in education had been drawn to the importance of resourcing and its availability in institutions of learning. The persistent belief that education holds the key to technological development, self-reliance and manpower development has since provided the conceptual framework and empirical justifications through which the educational policies and plans of developing countries have defined and elaborated their national goals. This was the philosophy behind the words of the former President of Tanzania, President Nyerere, when, referring to the Tanzanian organization Education for Self Reliance, he wrote:

'[It is] only when we are clear about the kind of society we are trying to build that we can design our goals.' (Nyerere, 1967, pp 15-52).

In this regard, Ekpo (1989) describes manpower development in terms of unskilled and/or skilled people who need training or retraining to perform specific tasks in a society. Omodia (2009) and Foo Seong (2008) suggest that manpower development can be seen as organization-specific and, broadly, a societal goal for many countries. A case in point is Nigeria, which emphasizes manpower development in its National Policy on Education (FRN, 2004). Omodia (2009) suggests that manpower development could also be viewed as the adaptation of the human resources available in the country to the needs, objectives and orientation of a given organization. For him, it is 'generic', because of its focus on turning out human resources needed for the development of the state (see also Drucker, 1999). As such, writers on manpower development concepts and theories view people as the most important asset in the society (see Ekpo, 1989; Drucker, 1999; Boom and Wee Him, 2008). From Omodia (2009), a typical example of the manifestation of this concept and these theories could be viewed from the perspective of the Nigerian educational system which is based on the 6-3-3-4 system which sought to address the manpower

needs of the country through mechanisms geared towards developing manpower that would boost the nation's socio-economic and technological advancement (FRN, 1998). The 6-3-3-4 system refers to six years in primary education, three years in junior secondary education, three years in senior secondary education and a minimum of four years in tertiary education.

\section{Statement of the problem}

Since the time of Nigerian Independence in 1960, 'most of the planners and policy makers have perceived their greatest problem as that of inadequate manpower both in quantitative and qualitative terms' (Aina, 2005, p 72). The Ashby Commission, set up by Federal Government in 1959 to conduct an investigation into Nigeria's needs in the field of post-school certificate and higher education, identified manpower development as a crucial need of the country. In its report, the Commission emphasized the "need for a National Manpower Board for the coordination of manpower policy and effective manpower development and utilization throughout the federation on a continuous basis' (Aina, 2005, pp 70-71). The role of higher education in combatting the manpower problem is also emphasized. Higher education institutions, as is the case with many other organizations, complain of inadequate funding (Diejomaoh, 1982; Okunamiri, 2002) and this is reflected in their budgets (Potokri, 2005). The essential problem confronted by higher education in sub-Saharan Africa is not limited to quality but also extends to the availability of funds commensurate with increasing enrolment rates and the inability to take the necessary actions (AAU, 1997). Following this, the problem identified as the subject of this research arises from the conditions underlying the availability of financial resources in Nigerian monotechnics education and the likelihood that relationships - in particular, relationships concerning manpower development in the country might emerge.

\section{Research questions and hypotheses}

Two questions were formulated.

(1) Is there a difference in financial resources availability in privately-owned and publicly-owned monotechnics?

(2) What is the level of the relationship between financial resources availability and manpower development in monotechnics?

In an attempt to answer these questions, hypotheses were developed.

\section{HO1: There is no significant difference in} availability of financial resources in publicly-owned monotechnics and privately-owned monotechnics.

HO2: There is no significant relationship between financial resources and manpower development in monotechnics.

\section{Conceptualization}

In an attempt to conceptualize this research topic, the combination of the relevance of manpower development and the problem of manpower development in Nigeria 
was regarded as an important key for understanding and analysing the data gathered from respondents. The choice of conceptualization is tied to the knowledge (as illuminated in the literature) that education holds the key to technological development, self-reliance and manpower development (Nyerere, 1967; Nwankwo, 1988; Boom and Wee Him, 2008)

The relevance of manpower development in Nigeria can be linked to economic development, because manpower development captures the actual meaning of development, in that it is people-centred (World Bank, 1991). In addition, it involves the building of capacity and the harnessing of the state's human resources which constitute a sine qua non for development (Omodia, 2009). From a different stance, Robb (2000) relates the relevance of manpower development to poverty when he describes this development as an important pill for poverty-related problems. Specifically, he argues that an effective poverty alleviation scheme must involve the development and utilization of local resources including human resources - in order to solve local problems (Robb, 2000). Thus, manpower development can be regarded as central to solving the present problem of poverty in Nigeria (Omodia, 2005).

While the relevance of manpower development is tied mainly to economic development vis-à-vis human capacity building, its core problems arise from distortions that emanate from past experience and lack of political will, as well as from the leadership deficiencies of politicians.

According to Ekpo (1989) and Dauda (2003), there have been several arguments regarding the distortions in manpower development linked with national growth in Nigeria; these distortions arising as a result of colonialism are fashioned towards economic exploitation. Omodia (2009) recalls that the advent of colonialism led to the integration of the Nigerian economy into the world capitalist system, thereby placing a minimum premium on labour when compared to other factors of production. In his view, this poor performance of indigenous labour has seemingly persisted in the post-colonial Nigerian state. As a result, this problem accounts for the lack of adequate attention given to labour as a critical part of the production process.

There are neither individual(s) nor countries without a past. What is evident from the above is the influence of that past - in other words, the influence of colonialism on manpower development. Nevertheless, several countries and organizations have moved beyond their pasts, characterized by underdevelopment and the placement of a minimum premium on labour and now operate in a state where human resources are highly prioritized. It would therefore be most unjust to blame colonialism for woes identified with manpower development without also faulting leadership across the spectrum - particularly political leadership which has been saddled with corruption and incompetence.

This corrupt and corrupted leadership has manifested itself in poor funding of education over the years (Baikie, 2002), disparities in manpower development between children of the rich and the children of the poor (Omodia, 2006) and the frequent or persistent closure of educational institutions, especially institutions of higher education, due to the poor funding - as often cited by the Academic Staff Union of Universities, amongst others. In addition, Baikie (2002) and Oku (2003) suggest that poor manpower planning in Nigeria is a further problem, closely associated with poor-quality databases on manpower statistics. In their interpretations, they refer to their knowledge of skilled, semi-skilled and unskilled personnel in the country. Where this knowledge is absent in terms of the numbers available or required, how then can planning in this regard be meaningful? This problem, according to Baikie (2002), is, in no small measure, a major obstacle to effective manpower development in Nigeria.

\section{Research method and design}

This descriptive quantitative research is based on the positivist paradigm and was aimed at evaluating the availability of financial resources and manpower development in monotechnics in Nigeria. Quantitative research, according to Blanche et al (2006, p 563), is research in which data are collected or coded into numerical forms, and to which statistical analyses may be applied to determine the significance of the findings. With data or responses coded into numbers or numerical forms, the formulated null hypotheses ( $\mathrm{HO} 1$ and $\mathrm{HO} 2$ ) can be scientifically tested.

\section{Population and sampling}

The population of the study consisted of monotechnics in Nigeria. Having considered sampling options, convenient sampling was embraced and used on the basis that funding available to travel across the various states of Nigeria in order to access monotechnics was inadequate - particularly in view of this being self-funded research. The research was thus limited to monotechnics in Lagos State, the former capital city of Nigeria and a densely populated state. Monotechnics that served as the research samples included two government-owned and two privately-owned monotechnics. Fifty students, 10 academic staff and 10 non-academic staff were randomly selected from each 
institution sampled, a total of 200 students and 80 staff serving as respondents.

\section{Research instrument}

Two questionnaires were designed for the task of gathering data: a student questionnaire and a staff questionnaire. Given that it was the researcher's aim to elicit the responses of different respondents to the same questions, the sets of questions for both questionnaires were identical. The questionnaires differed in that the version presented to staff contained one additional section consisting of a few questions based mainly on the revelation of the conceptual framework. It was the view of the researcher that these questions could best be answered by staff and this justified having the added section. Questions in this added section related to the political leadership problem, the poor implementation of manpower development plans, and poor remuneration. Responses were recorded on a four-point Likert scale with the following choices offered: Strongly Agree (SA) - 5 points; Agree (A) - 4 points; Disagree (SD) 3 points; and Strongly Disagree (D) -2 points.

\section{Validity, reliability and administration of the research instrument}

Before the questionnaires were administered to the respondents they were validated, which involved presenting the questionnaires to senior colleagues in academia, some of whom had published and written extensively on similar or related research. The final version of the questionnaire incorporated the comments and suggestions of these colleagues.

To determine the reliability of the research instrument (questionnaire), the test-retest method was used (see Blanche et al, 2006). Accordingly, the questionnaire was administered to 100 students and 40 staff from different but similar institutions in the Delta state of Nigeria.

\section{Data analysis}

The data collected were analysed via chi-square statistics and Pearson product moment correlation. The chi-square statistical method was used to test hypothesis 1 because this hypothesis emphasized the difference between two variables (Blanche and Durrheim, 1999). The Pearson product moment correlation was used to test hypothesis 2 because it emphasized the relationship between two variables (Blanche and Durrheim, 1999).

Given that this research was located within the positivist paradigm, as noted earlier, the analysis and reporting required that affirmative answers be provided in respect of either the research questions or of the hypotheses. In other words, it was necessary to show that only one reality existed. This implies that the researcher was more interested in a precise answer or response to each question/hypothesis and not in divergent views.

\section{Ethical issues}

Responsibility for the ethical conduct of the research was vested in the researcher (APA, 1992). To fulfil this responsibility, letters were written and sent to the heads and administrators of the institutions targeted for sampling. The letters requested permission to conduct the research in the institutions concerned. Those institutions that responded favourably were then visited in order to appraise the prospective respondents of what was required of them. Once willing respondents (students and staff) had been identified, each was sent an official letter addressing issues of confidentiality, anonymity, informed consent, voluntary participation and the purpose of the research.

\section{Data analysis}

The data collected for this research are presented and analysed in this section. The analysis was carried out as described in the methodology section and in accordance with the hypotheses generated for the study.

\section{Hypothesis 1: There is no significant difference between availability of financial resources in publicly-owned monotechnics and privately-owned monotechnics.}

Table 1 shows the proportions of respondents in each of the four institutions sampled (two public, two private) who responded affirmatively - that is, either Agreed or Strongly Agreed - to the question ('Is there a difference. ..'). The responses of all respondents in each institution sampled were collapsed and converted to percentages.

These percentages are recorded as the observed values. The expected value in each case is 100 because of the conversion to percentage. Appendix A provides a statistical computation of the data in Table 1 .

\section{Decision}

The null hypothesis that there is no significant difference between financial resources availability in publicly-owned and privately-owned monotechnics is therefore accepted because:

(1) The calculated value, 138.2 , is greater than table value 7.82. That is, $X^{2} \mathrm{Cal}>X^{2}$ Table (see Appendix A); and 
Table 1. Responses to the question, 'Is there a difference in financial resources availability in privately-owned and publicly-owned monotechnics?'

\section{Institution}

School of Fisheries and Oceanography (public) Nigeria French Language Village(public)

Lagos City Computer College (private)

Nigerian College of Administration (private)

\section{Affirmative response rate}

$48 \%$

$51 \%$

$32 \%$

$36 \%$
(2) The calculated value, 138.2, is greater than 100 (percentage) (see Appendix A).

Hypothesis 2: There is no significant relationship between financial resources provision and manpower development.

In an attempt to test Hypothesis 2, responses on provision of financial resources and its impact on manpower development in monotechnics were used: see Tables 2 and 3.

Table 2 shows the response(s) of students and staff regarding adequacy of financial resources in the monotechnics sampled. Of the total of 200 students, 18 were of the opinion that availability of financial resources was adequate, but 182 believed the availability was inadequate: specifically, 100 disagreed strongly and 82 disagreed that the availability of financial resources was adequate. There were also responses regarding the state of manpower development in their institutions of learning, from students and staff: Table 3 shows the numerical results. Of the students, 98 and 85 strongly agreed and agreed, respectively, that manpower development depended on financial resources provided or available in their institutions. However, 5 and 12 students disagreed and strongly disagreed, respectively, that manpower did not depend on financial resources made available to monotechnics. With respect

Table 2. Student and staff responses in respect of financial resources provision adequacy in monotechnics.

\begin{tabular}{lllll}
\hline & SA & A & D & SD \\
Students & 3 & 15 & 82 & 100 \\
Staff & 2 & 1 & 7 & 70 \\
\hline
\end{tabular}

Table 3. Student and staff responses regarding the impact of financial resources on manpower development in monotechnics.

\begin{tabular}{lllll}
\hline & SA & A & D & SD \\
Students & 98 & 85 & 5 & 12 \\
Staff & 65 & 12 & 1 & 2 \\
\hline
\end{tabular}

to staff responses, 65 and 12, respectively, strongly agreed and agreed that manpower development in monotechnics depended on the financial resources available to institutions of learning; but three members of staff were of the opinion that manpower development in monotechnics did not depend on financial resources. Appendix B provides details of the statistical computation and collapse of Tables 2 and 3 .

\section{Decision}

Based on the result of the correlation, $r=-0.467$ (see Appendix B), the null hypothesis (HO3) is upheld. Analysis of the data reveals that the relationship is not significant at -1 . Thus, the hypothesis should be rejected.

\section{Outcomes}

The outcomes of this research are derived from the results and decisions on the hypotheses tested. For the sake of brevity, the findings are classified into two groupings and in accordance with the research questions.

Question 1: Is there a difference in financial resources availability in privately-owned and publicly-owned monotechnics?

This research finds that, according to those who participated in the questionnaire surveys, financial resources provided for or otherwise available to either privately or publicly-owned monotechnics are inadequate and are not different for each type of monotechnic. This suggests that neither private nor public monotechnics are well funded. The answer to this question could be regarded as 'non-concrete' but relative, given that the budgets of the institutions sampled were not accessed and thus could not be used to determine whether there was a difference in the amount of financial resources available to privately and publicly-owned monotechnics. However, relying on the responses and in particular the tested hypothesis (HO1), the answer to this question, that there is no difference, is justifiable. 
If, then, the financial resources provided for or otherwise available to monotechnics are inadequate, it can be argued that manpower development - one of the major aims or objectives of establishing monotechnics is negatively affected because both variables are interdependent. For instance, studies by Baikie (2002) and Omodia, (2006) indicate that manpower development is negatively influenced by poor or inadequate funding. Since the present research is quantitative in design and methodology, no detailed explanations were offered by, or indeed expected of, respondents as to how the inadequacy of financial resources affects manpower development.

However, the answers provided to the questions that made up the questionnaires administered to staff and students give a strong indication, because a detailed inspection of all the responses on the effect of finance on the availability of educational equipment, study materials, staff development and laboratories provides sufficient evidence that inadequate financial resources do indeed affect manpower development, because 'human capacity building' (the term sometimes used in the literature for manpower development) depends largely on the questions that made up the questionnaire. This research does not view manpower development from the stance of quantity (the number of personnel), but rather from a stance of quality (skills acquired). Therefore, by inference, graduates of monotechnics are not properly equipped with the skills, knowledge and innovations required for societal advancement, as emphasized in Nigeria's national education policy. This is because skills facilitators such as classrooms, laboratories, teachers, study materials - all factors raised in the questionnaire - are inadequate and, in some cased, perhaps obsolete.

\section{Question 2: What is the level of the relationship between financial resources availability and manpower development in monotechnics?}

This research highlights the relationship between availability of financial resources and manpower development in monotechnics. In brief, it unfolds and supports the views of Nwankwo (1988), Okunamiri (2002) and Foo Seong (2008) that a relationship does exist between financial resources and manpower development. The new aspect of this research is that it establishes clearly that the relationship between the two variables (financial resources availability and manpower development) in Nigerian monotechnic education is significant. This suggests that the variables are both dependent and interdependent - hence the availability or unavailability of one will result in either a positive or a negative effect on the other. In this case, and based on the questionnaire responses, the inadequate availability of financial resources accounts for manpower development problems in the institutions sampled.

\section{Discussion of findings}

The conceptual implications of this research are crucial with regard to studies of educational policy and manpower development. It is evident from this research that financial resources are essential in the development of manpower and, as such, a lack of these resources negatively influences the actualization of the goals and objectives of monotechnics. This research not only reveals that financial resources in selected monotechnics are insufficient for the smooth running of these institutions, it also corroborates the findings of previous studies (see, for example, AAU, 1997) that the essential problem confronted by higher education is not limited to quality but extends to the availability of funds commensurate with increasing enrolment rates and an inability to take the necessary actions.

Importantly, the literature - see Ekpo (1989) and Drucker (1999) - suggests that human resources are the most important asset in any society. More important with regard to this research is the relationship between manpower development and financial resources. This research has established that there is a significant relationship between these two variables and that both are largely interdependent. As such, it would not be a wrong to regard financial resources as the bedrock of manpower development.

Other things being equal, the problems of manpower development affect economic development and growth, as illustrated in the conceptualization section of this paper. Stated differently, these problems, in concert with others, influence or affect manpower development. In agreement with Omodia (2009), and inferring from the responses received from respondents, these problems include political leadership, poor implementation of manpower development planning and poor remuneration. While this research did not seek to link poor remuneration to work attitude, it is the researcher's opinion - based on his experience as an administrator that the work attitude of staff could be affected, because this attitude depends to some extent on the financial resources available or that are provided. In line with this, lack of financial resources in monotechnics may have caused some of the problems indicated by respondents, such as inadequate student accommodation, inadequate office space for staff, and power outages. However, the problem of inadequate accommodation was not common to all the institutions sampled because the private monotechnics that formed part of the sample were non-residential institutions. This was revealed because respondents from such institutions 
did not respond to the question on inadequate accommodation for students.

\section{Conclusion and recommendations}

This study suggests that financial resources are a pivotal factor with regard to skills development; that is, manpower development. In addition, it exposes the lack of classrooms and office space, inadequate and obsolete laboratories, and the particular problem, amongst others, of power outages in the institutions sampled. Manpower development, a problem since the beginning of Nigerian independence, could be expected to improve, perhaps considerably, given the availability of adequate financial resources. The effect of this outcome could be far-reaching, given that financial resources in both private and public owned monotechnics are inadequate and that the relationship between both (financial resources and manpower development) is found to be statistically significant.

Based on the findings, and cognisant of the objectives of monotechnics in Nigeria, it is suggested that improvement and development of middle and high level manpower is essential for self-reliance, especially for graduates of monotechnics. To this end, owners of monotechnics are encouraged to provide adequate financial resources - that is, funding that will match the needs of these institutions - so that these institutions can implement their programmes effectively and efficiently in relation to their general philosophy and their general objectives. Further, five recommendations are made, as follows.

First, government should make provision for loan/grants for graduates to start out in their own trades or professions. This would boost self-reliance and mean that people would be less dependent on the government for jobs. It can be anticipated that eventually there would be more job creators than job seekers in the country.

Second, seminars, workshops and conferences should be held from time to time to educate students, parents and the public as a whole, especially at grassroots level, about both the significance of monotechnics and the importance of manpower development.

Third, stakeholders in education should ensure that attention is not drawn to or focused only on universities, polytechnics and colleges of education. The monotechnics should be equally considered and given due regard.

Fourth, the educational equipment and infrastructures in monotechnics should be improved and supplemented where necessary. This would go a long way towards helping to increase the interest of students seeking admission into these institutions. Furthermore, it would help to foster the learning attitude of prospective graduates, making them better in their respective fields of specialization, all of which would lead to better prospects or to an injection of manpower input. To this end, the implementation of capital grants is suggested.

Fifth, and lastly, the managers of monotechnics should seek international assistance and develop related strategies with regard to alternative or additional means of generating financial resources to complement the resources available from government or the owners of the institutions. They can do so by introducing new courses that are both relevant to current challenges and interesting for prospective students to study. In addition, subsidiary ventures within the campus should be established, where students can put into practice what they have learnt while also making money for the institution and themselves.

\section{References}

Aina, S. (2005), Managing the Human Capital in Nigeria, Fountain Training Consult, Ikeja, Lagos.

APA (1992), 'Ethical principles of psychologists and code of conduct', American Psychologist, Vol 47, pp 1597-1611.

AAU (Association of African Universities) (1997), Revitalizing Universities in Africa: Strategy and Guidelines, World Bank, Washington, DC.

Baikie, A. (2002), Recurrent Issues in Nigeria Education, Tamaza Publishing Company, Zaria.

Blanche, M.T., and Durrheim, K. (1999), Research in Practice: Applied Methods for the Social Sciences, University of Cape Town Press, Cape Town.

Blanche, M.T., Durrheim, K., and Painter, D. (2006), Research in Practice: Applied Methods for the Social Sciences, 2nd edition, University of Cape Town Press, Cape Town.

Boom G.C., and Wee Him, L.T. (2008), 'The development of university education in Singapore', in Lee, S.K., Goh, C.B., Frederiksen, B., and Tan, J.P., eds, Towards a Better Future: Education and Training for Economic Development in Singapore Since 1965, National Institute of Education, Singapore and World Bank, Washington DC.

Campbell, O. (2003), Financial Management and Accountability in Education, Babs Olatunji Publishing Company, Lagos.

Dauda, S. (2003), 'The crisis of development in Africa: the democratic imperatives', Journal of Developing Societies, Vol 1, No 4, pp 84-87.

Diejomaoh, V.P. (1982), 'Development of manpower in Nigeria', Management Magazine, November, p 4.

Drucker, P.F. (1999), Management Challenges for the 21st Century, Harper Business, New York.

Ekpo, A.H. (1989), 'Manpower development in Nigeria', in Ogbuagu, S.C., ed, Strategy For National Development in Nigeria, University of Calabar Press, Calabar, pp 143-154.

Farzaneh, R., and Moghadam, V.M. (2003), 'Empowering women, developing society: female education in the Middle East and North Africa', Population Reference Bureau, Washington DC,http://www.prb.org/Publications/Reports/ 2003/EmpoweringWomenDevelopingSocietyFemale EducationintheMiddleEastandNorthAfrica.aspx (accessed 21 August 2014).

FRN (1998), National Policy on Education, Federal Government Press, Lagos.

FRN (2004), National Policy on Education, 4th ed, WERDC, Yaba, Lagos. 
Foo Seong, D.N. (2008), 'The development of university education in Singapore', in Lee, S.K., Goh, C.B., Frederiksen, B., and Tan, J.P., eds, Towards a Better Future: Education and Training for Economic Development in Singapore Since 1965, National Institute of Education, Singapore and World Bank, Washington DC.

JAMB (2011), Guideline for admission to polytechnics, monotechnics and colleges of education in Nigeria.

Nwankwo, G.O. (1988), Education and training for public management in Nigeria, University Publishing Company, Ibadan.

Nyerere, J. (1967), 'Education for self-reliance', Ministry of Information, Dar-es-Salaam.

Ogbogu, C.O. (2011), 'Modes of funding Nigerian universities and the implications on performance', paper presented at the 2011 European Academic Conference, 6-9 July, Barcelona.

Oku, O. (2003), 'The universal basic education (UBE) programme: issues and problems of policy implementation', Journal of Nigerian Languages and Culture, Vol 5, No 1, pp 32-36.

Okunamiri, P.O. (2002), Resourcing and Guidelines for Educational Finance in Tertiary Institutions in Nigeria, Fasmen Educational and Research Publications and Fasmen Communications, Okigwe.

Omodia, S.M. (2005), 'Poverty alleviation in a deregulated economy: challenges and prospects for sustainable democracy in Nigeria', Nasarawa Journal of Administration, Vol 2, No 1, pp 118-124.
Omodia, S.M. (2006), 'The liberal and elitist perception of public policies in Nigeria: a focus on the national policy on women and education in the Nigerian Fourth Republic', Acad For, 10(2): 35-39.

Omodia, S.M. (2009), 'Manpower development in Nigeria: conceptual and methodological perspectives', Journal of Social Sciences, Vol 18, No 2, pp 113-117.

Potokri, O.C. (2005), 'Financial resources and manpower development in monotechnic education in Nigeria', unpublished MEd Thesis, Lagos State University, Ojo, Nigeria.

Potokri, O.C. (2011), 'Academic performance of married women students in Nigerian higher education', unpublished PhD thesis, University of Pretoria, Pretoria.

Potokri O.C. (2013), Eternal Investment: Perspective of an Economist, Free Enterprise Publishers, Lagos.

Robb, C.M. (2002), Can the Poor Influence Policy? World Bank, Washington DC.

Saint, W., Hartnett, T., and Strassner, E. (2003), 'Higher education in Nigeria: a status report', Higher Education Policy, Vol 16, pp 259-281.

Teferra, D., and Altbach, P.G. (2004), 'African higher education:

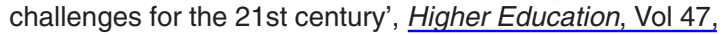
pp 21-50.

World Bank (1991), 'The African capacity building initiative: toward improved policy analysis and development management', World Bank, Washington DC.

\section{Appendix A}

Table A1. Statistical computation of Table 1 (responses on the difference in financial resources availability in publicly-owned and privately-owned monotechnics).

\begin{tabular}{llllll}
\hline Institution & $\begin{array}{l}(\mathbf{O}) \\
\text { response }\end{array}$ & $(\mathrm{E})$ & $(\mathbf{O}-\mathrm{E})$ & $(\mathbf{O}-\mathrm{E})^{2}$ & $\frac{(\mathbf{O}-\mathrm{E})^{2}}{\mathrm{E}}$ \\
$\begin{array}{l}\text { School of Fisheries } \\
\text { and Oceanography }\end{array}$ & 48 & 100 & 52 & 2704 & 27.0 \\
$\begin{array}{l}\text { Nigeria French } \\
\text { Language Village }\end{array}$ & 51 & 100 & 49 & 2401 & 24.0 \\
$\begin{array}{l}\text { Lagos City } \\
\text { Computer College }\end{array}$ & 32 & 100 & 68 & 4624 & 46.2 \\
$\begin{array}{l}\text { Nigerian College of } \\
\text { Administration }\end{array}$ & 36 & 100 & 64 & 4096 & 41.0 \\
& 167 & 400 & 233 & 7013 & 138.2 \\
\hline
\end{tabular}

$X^{2}($ chi-squared $) \quad=\Sigma \frac{(\mathrm{O}-\mathrm{E})^{2}}{\mathrm{E}}$

Degrees of freedom $=(4-1)=3$

Level of significance $=0.05$

$X^{2}$ (table value) $\quad=7.82$ 


\section{Appendix B}

Table B1. Statistical computation and collapse of Tables 2 and 3.

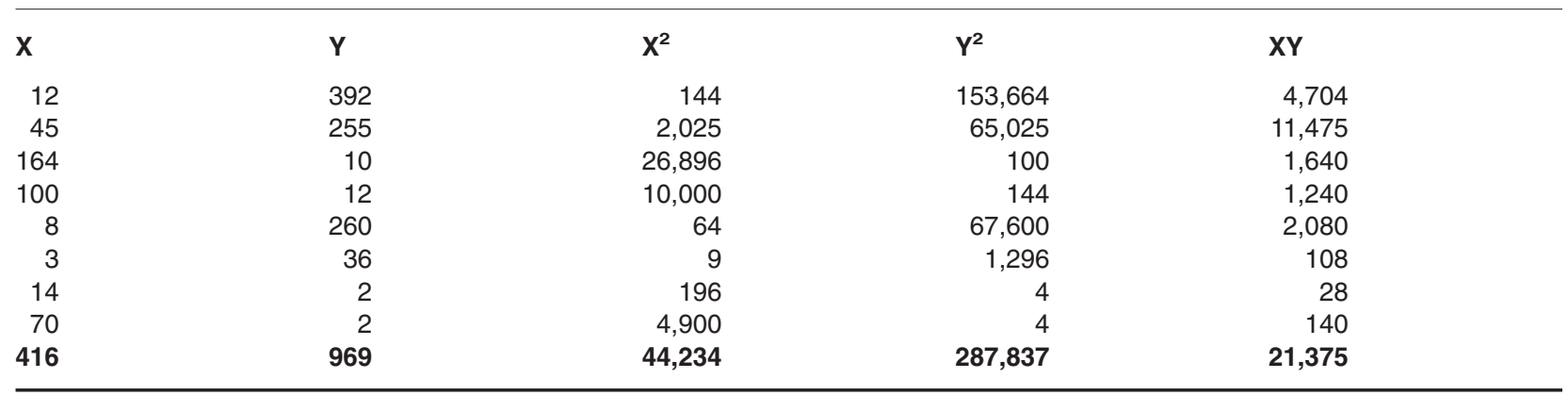

To obtain values of $X$ and $Y$, the points for response, that is, SA (4 points), A (3 points), D (2 points), SD (1 point) are used: that is, multiplied by responses.

$X$ - represents responses in respect of financial resources provision

$Y$ - represents responses in respect of manpower development

Pearson's product moment correlation co-efficient $(r)$ is given by this equation:

$$
r=\frac{N \Sigma x y-(\Sigma x)(\Sigma y)}{\sqrt{\left(N \Sigma x^{2}-(\Sigma x)^{2}\right)\left(N \Sigma y^{2}-(\Sigma y)^{2}\right)}}
$$

Thus, in this case:

$\mathrm{r}=-0.467$

and therefore

$\mathrm{r}=-1$ (approximately). 